\title{
PENGEMBANGAN PERANGKAT PEMBELAJARAN DENGAN PENDEKATAN QUANTUM LEARNING PADA MATA KULIAH ALJABAR LINIER MATERI RUANG-n EUCLIDES
}

\author{
Tri Andari
}

\begin{abstract}
Abstrak
Penelitian ini bertujuan menghasilkan perangkat pembelajaran dengan pendekatan Quantum Learning pada mata kuliah Aljabar. Penggunaan pendekatan Quantum Learning dalam pembelajaran merupakan salah satu cara untuk menarik minat mahasiswa dalam mengikuti dan memahami materi Aljabar Linier, karena dalam pendekatan pembelajaran ini (Quantum Learning) sangat memperhatikan lingkungan belajar yang didesain sedemikian hingga peserta didik merasa penting, aman, nyaman, senang, dan dapat belajar secara optimal. Pendekatan Quantum Learning dipadukan dengan metode yang cocok yang diharapkan dapat meningkatkan keaktifan mahasiswa sehingga dapat mendorong mahasiswa untuk mempelajari materi-materi tersebut dengan lebih baik. Penelitian pengembangan ini dilakukan menggunakan pendekatan pengembangan 4-D Thiagarajan, dkk.. Keempat tahap tersebut adalah tahap pendefinisian, tahap perancangan, tahap pengembangan, dan tahap penyebaran. Perangkat pembelajaran yang didapatkan telah dinyatakan valid oleh para validator dan memenuhi kriteria yaitu aktivitas mahasiswa efektif, kemampuan dosen mengelola pembelajaran baik, kemampuan mahasiswa dalam memahami materi baik, tes hasil belajar sensitif, valid, dan reliabel, serta respon mahasiswa positif. Perangkat pembelajaran yang dihasilkan meliputi SAP, LKM, dan THB pada mata kuliah Aljabar Linier.
\end{abstract}

Kata Kunci: Pengembangan, Pendekatan Pembelajaran, Quantum Learning, Aljabar Linier.

\section{Pendahuluan}

Matematika Pembelajaran matematika di tanah air saat ini sedang mengalami perubahan paradigma dari pembelajaran yang berpusat pada guru menjadi pembelajaran yang berpusat pada siswa. Paradigma baru pembelajaran matematika lebih menekankan pada peserta didik sebagai 
manusia yang memiliki potensi untuk belajar dan berkembang. Guru harus mengubah perannya, tidak lagi sebagai pemegang otoritas tertinggi keilmuan dan indoktriner, tetapi menjadi fasilitator yang membimbing peserta didik ke arah pembentukan pengetahuan oleh diri mereka sendiri.

Dalam kenyataannya praktek pembelajaran matematika di Indonesia selama ini masih berpusat pada guru. Selain itu kebanyakan peserta didik di sekolah beranggapan bahwa belajar matematika tidak menyenangkan dan hanya menjadi rutinitas tanpa diiringi kesadaran untuk menambah wawasan. Meskipun matematika diajarkan dengan prosentase jam pelajaran yang lebih banyak, namun prestasi siswa dalam bidang matematika relatif rendah.

Ruang-n Euclides merupakan salah satu materi pada mata kuliah Aljabar Linier yang dipelajari oleh mahasiswa Program Studi Pendidikan Matematika semester $\mathrm{V}$. Mata kuliah ini merupakan mata kuliah prasyarat untuk beberapa mata kuliah yang lain. Dari data nilai mahasiswa semester $V$ menunjukkan prosentase nilai mata kuliah Aljabar Linier di atas 70 hanya $35,40 \%$ sedangkan sisanya mendapat nilai di bawah 70 . Presentase ini relatif rendah jika dibandingkan mata kuliah yang lain.

Prinsip-prinsip pembelajaran dengan pendekatan kontruktivisme telah melahirkan berbagai macam pendekatan pembelajaran yang inovatif. Beberapa pendekatan pembelajaran yang dipandang efektif untuk mempercepat pencapaian kompetensi dasar peserta didik adalah pendekatan Quantum Learning. Pendekatan ini dilakukan dengan mengubah bermacam-macam interaksi yang ada di dalam dan di luar lingkungan belajar. Lingkungan belajar yang menyenangkan akan mampu menggabungkan rasa percaya diri, keterampilan belajar, dan keterampilan berkomunikasi. Itulah yang ditawarkan DePorter \& Hernacki [1] dalam pendekatan pembelajaran temuannya “Quantum Learning”.

Materi Ruang-n Euclides merupakan salah satu materi dalam Aljabar Linier yang yang memuat konsep-konsep yang beragam, sehingga mahasiswa seringkali mendapat kesulitan dalam memahaminya. 
Pengembangan Perangkat Pembelajaran Dengan Pendekatan Quantum Learning Pada Mata Kuliah Aljabar Linier Materi Ruang-n Euclides

Penggunaan pendekatan Quantum Learning merupakan salah satu cara untuk menarik minat mahasiswa dalam mengikuti dan memahami materi pada mata kuliah Aljabar Linier, karena dalam pendekatan pembelajaran ini sangat memperhatikan lingkungan belajar yang didesain sedemikian, sehingga peserta didik merasa penting, aman, nyaman, senang, dan dapat belajar secara optimal.

Berdasarkan pengamatan di tempat peneliti mengajar, sampai saat belum tersusun suatu perangkat pembelajaran yang dapat dijadikan panduan mengajar mata kuliah Aljabar Linier khususnya pada materi Ruang-n Euclides. Dengan perangkat pembelajaran yang dihasilkan tersebut diharapkan dapat memotivasi mahasiswa supaya lebih kreatif dalam memecahkan masalah, mampu berkomunikasi secara matematik, mengaitkan suatu konsep dengan konsep yang lain ataupun dengan kehidupan nyata, serta mampu bernalar secara logis dan sistematis dalam mempelajari materi pada mata kuliah Aljabar Linier khususnya pada materi Ruang-n Euclides.

Tujuan yang diharapkan dapat diperoleh melalui penelitian ini adalah menghasilkan perangkat pembelajaran yang baik dengan menggunakan pendekatan Quantum Learning pada mata kuliah Aljabar Linier materi Ruang-n Euclides.

Rumusan masalah yang dirumuskan berdasarkan latar belakang yang diuraikan di atas adalah bagaimana pengembangan dan hasil pengembangan perangkat pembelajaran yang baik dengan menggunakan pendekatan Quantum Learning pada mata kuliah Aljabar Linier?

\section{Metode Penelitian}

\section{Rancangan Penelitian}

Desain penelitian yang digunakan merupakan penelitian pengembangan (developmental research). Penelitian pengembangan dilakukan untuk mengembangkan perangkat pembelajaran pada mata kuliah Aljabar Linier. Rancangan penelitian di uji coba terlebih dahulu 
yang berbentuk One Group Pretest-Posttest Design sebagaimana disajikan pada Tabel berikut:

Tabel 1. Rancangan Penelitian Uji coba

\begin{tabular}{|c|c|c|c|}
\hline Kelas & $\begin{array}{c}\text { Tes } \\
\text { Awal }\end{array}$ & Perlakuan & $\begin{array}{c}\text { Tes } \\
\text { Akhir }\end{array}$ \\
\hline Eksperimen & $\mathrm{T}_{\mathrm{aw}}$ & $\mathrm{X}$ & $\mathrm{T}_{\mathrm{ak}}$ \\
\hline
\end{tabular}

Keterangan:

$\mathrm{T}_{\mathrm{a}}$ : tes awal, tes sebelum perlakuan

$X$ : pembelajaran dengan pendekatan Quantum Learning

$T_{a k}$ : tes akhir, tes setelah perlakuan

\section{Subjek Penelitian}

Penelitian ini dilaksanakan pada mahasiswa semester $\mathrm{V}$ Prodi Pendidikan Matematika FPMIPA IKIP PGRI Madiun. Subjek penelitian uji coba adalah mahasiswa semester $V$ kelas B Prodi Pendidikan Matematika FPMIPA IKIP PGRI Madiun. Kelas ini dipilih secara acak karena mahasiswa di setiap kelas yang ada di Program Studi Pendidikan Matematika FPMIPA IKIP PGRI Madiun memiliki kemampuan yang beragam.

\section{Prosedur Penelitian}

Pendekatan pengembangan perangkat pembelajaran pada penelitian ini adalah model Thiagarajan, Semmel, dan Semmel yang dikenal dengan four-D model (model 4-D) dalam Trianto (2009). Model Thiagarajan terdiri dari 4 tahap yang dikenal dengan pendekatan 4-D (four D pendekatan). Namun dalam penelitian ini hanya dibahas tentang tiga tahap yaitu tahap pendefinisian (define), tahap perancangan (design), dan tahap pengembangan (development). Instrumen dan pengumpulan data yang digunakan dalam penelitian ini meliputi lembar validasi, lembar validasi keterbacaan, lembar observasi (pengamatan), angket respon mahasiswa, dan tes hasil belajar.

\section{Analisis Data}

Data hasil penilaian para ahli untuk masing-masing perangkat dianalisis berdasarkan skor rata-rata. Perangkat pembelajaran dikatakan 
Pengembangan Perangkat Pembelajaran Dengan Pendekatan Quantum Learning Pada Mata Kuliah Aljabar Linier Materi Ruang-n Euclides

valid menurut para validator jika para validator memberikan penilaian minimal 3. Analisis Keterbacaan data tentang hasil validasi mahasiswa terhadap isi LKM, penampilan LKM. Kemampuan dosen dalam mengelola pembelajaran dikatakan baik jika rata-rata skor dari setiap aspek pada setiap pertemuan minimal 3. Aspek-aspek yang tidak memenuhi kategori minimal tersebut, akan dijadikan sebagai bahan pertimbangan dalam merevisi perangkat pembelajaran.

Presentase aktivitas mahasiswa ditentukan berdasarkan alokasi waktu yang direncanakan pada rencana pembelajaran. Keefektifan aktivitas mahasiswa ditentukan oleh kesesuaian terhadap aktivitas ideal yang ditetapkan. Aktivitas mahasiswa dikatakan efektif jika memenuhi kriteria batasan keefektifan pembelajaran mencapai 60\% dalam melakukan aktivitas berdasarkan 10 aspek pengamatan. Aspek-aspek yang tidak memenuhi kriteria efektif akan dijadikan bahan pertimbangan untuk merevisi perangkat pembelajaran.

Kemampuan mahasiswa dalam memahami materi dikatakan baik jika nilai rata-rata kemampuan mahasiswa dalam memahami materi yang diamati minimal 3. Lembar pengamatan kemampuan mahasiswa dalam memahami materi digunakan untuk mengumpulkan data kemampuan mahasiswa dalam memahami materi. Kriteria penilaian yang diberikan, meliputi: nilai 1 (sangat tidak baik), nilai 2 (tidak baik), nilai 3 (baik) dan nilai 4 (sangat baik). Pengamatan dilakukan oleh seorang pengamat. Pengamatan dilakukan dengan cara melingkari angka pada kolom skor $(1,2,3,4)$ sesuai dengan kriteria pada lembar pengamatan kemampuan mahasiswa dalam memahami materi.

Respon mahasiswa dikategorikan positif jika persentase respon positif mahasiswa minimal $80 \%$ untuk tiap aspek. Hasil analisis data tentang respon mahasiswa akan digunakan untuk merevisi perangkat pembelajaran. Analisis tersebut dilakukan terhadap data respon mahasiswa yang diperloleh pada penelitian ujicoba dan penelitian 
eksperimen. Analisis data tes hasil belajar dilakukan dengan penskoran, analisis butir soal, dan validitas butir, reliabilitas tes.

Butir soal dikatakan sensitif jika sensitivitas butir soal berada antara 0 dan 1 (Gronlund dalam Dara, 2009) dan jika $S>0,30$. Menurut Arikunto (2003) Instrumen dapat dikatakan valid jika dapat mengungkap data dari variabel yang diteliti dengan tepat.

Berdasarkan hasil perhitungan sensitivitas, validitas dan reliabilitas, maka dilakukan revisi terhadap Tes Hasil Belajar dengan menggugurkan atau mengganti butir-butir tes yang tidak layak digunakan. Setelah draft III direvisi, maka akan diperoleh draft IV. Sebelum digunakan pada eksperimen, sebaiknya draft IV dikonsultasikan lagi kepada para ahli. Berdasarkan uraian di atas, maka perangkat pembelajaran dikatakan baik jika perangkat pembelajaran tersebut memenuhi kriteria valid berdasar tim validator dan setelah diujicobakan.

\section{Hasil Penelitian Dan Pembahasan}

\section{Hasil Penelitian}

Perangkat pembelajaran yang dikembangkan dalam penelitian ini meliputi Satuan Acara Perkuliahan (SAP), Lembar Kegiatan Mahasiswa (LKM), dan Tes Hasil Belajar (THB). Model pengembangan perangkat pembelajaran pada penelitian ini adalah model Thiagarajan, Semmel, dan Semmel yang dikenal dengan four-D model (model 4-D) yang terdiri dari 4 tahap. Keempat tahap tersebut adalah tahap pendefinisian (define), tahap perancangan (design), tahap pengembangan (development), dan tahap penyebaran (disseminate). Namun, dalam penelitian ini yang digunakan hanya tiga tahap pengembangan perangkat, yaitu tahap pendefinisian, tahap perancangan dan tahap pengembangan.

\section{a) Deskripsi Tahap Pendefinisian(Define)}

Tahap ini bertujuan untuk menetapkan dan mendefinisikan kebutuhan-kebutuhan pembelajaran dengan menganalisis tujuan dan 
Pengembangan Perangkat Pembelajaran Dengan Pendekatan Quantum Learning Pada Mata Kuliah Aljabar Linier Materi Ruang-n Euclides

batasan materi. Tahap pendefinisian terdiri dari 5 langkah yaitu analisis awal-akhir, analisis mahasiswa, analisis konsep, analisis tugas dan spesifikasi tujuan pembelajaran

1) Analisis awal-akhir

Pada langkah ini peneliti melakukan observasi pada mahasiswa semester V Program Studi Pendidian Matematika IKIP PGRI Madiun untuk mengetahui masalah dasar yang terjadi di dalam pembelajaran pada mata kuliah Aljabar Linier. Setelah mengetahui masalah dasar yang terjadi, peneliti mencoba melakukan kajian pada kurikulum yang berlaku serta teori belajar yang mendukung sebagai upaya pemecahan solusi dari masalah tersebut. Hal ini yang menjadi latar belakang perlu atau tidaknya dikembangkan perangkat pembelajaran dengan pendekatan Quantum Learning.

\section{2) Analisis mahasiswa}

Pada langkah ini peneliti melakukan observasi untuk mengetahui kegiatan dan karakteristik mahasiswa yang sesuai dengan rancangan dan pengembangan perangkat pembelajaran yang sesuai dengan subjek penelitian. Karakteristik mahasiswa tersebut meliputi latar belakang pengetahuan dan perkembangan kognitifnya. Setelah melakukan observasi dan menelaah mengenai karakteristik mahasiswa semester $V$ Program Studi Pendidian Matematika IKIP PGRI Madiun peneliti memperoleh informasi tentang latar belakang pengetahuan mahasiswa dan perkembangan kognitif mahasiswa.

\section{3) Analisis konsep}

Pada langkah ini peneliti melakukan analisis pada konsep-konsep yang akan diajarkan pada kegiatan pembelajaran. Analisis ini bertujuan untuk mengidentifikasi, merinci dan menyusun secara sistematis konsep-konsep yang relevan yang akan diajukan berdasarkan analisis awal-akhir. 


\section{4) Analisis tugas}

Pada langkah ini peneliti melakukan analisis terhadap tugas-tugas berupa kompetensi yang akan dikembangkan dalam kegiatan pembelajaran. Kegiatan ini ditujukan untuk mengidentifikasi keterampilan akademis utama yang akan dikembangkan dalam pembelajaran.

\section{5) Spesifikasi tujuan pembelajaran}

Hasil analisis materi dan analisis tugas digunakan untuk merumuskan tujuan pembelajaran yang selanjutnya digunakan sebagai pedoman dalam menyusun Satuan Acara Perkuliahan (SAP), Lembar Kegiatan Mahasiswa (LKM), dan Tes Hasil Belajar (THB) materi Ruang-n Euclides.

\section{b) Deskripsi Tahap Perancangan (Design)}

\section{1) Pemilihan format}

Format yang digunakan pada SAP disesuaikan dengan prinsip, karateristik, serta langkah-langkah pembelajaran dengan menggunakan pendekatan Quantum Learning. Isi pembelajaran mengacu pada hasil analisis materi, tugas dan spesifikasi tujuan pembelajaran yang telah dirumuskan pada tahap pendefinisian.

\section{2) Pemilihan media}

Pemilihan media dilakukan sesuai dengan hasil analisis materi tugas karena penggunaan media bertujuan untuk memudahkan mahasiswa dalam memahami materi dan tugas yang diberikan. Berdasarkan hal tersebut, maka seperangat media dipilih adalah seperangkat slide Power Point yang berisi hal-hal yang dibahas pada LKM 1 dan LKM 2.

\section{3) Perancangan awal perangkat pembelajaran}

a. SAP yang dikembangkan dalam penelitian ini tentang materi Ruang-nEuclides. Susunan SAP berorientasi pada model dengan pendekatan Quantum Learningyang didalamnya memuat identitas SAP, alokasi waktu, standar kompetensi, 
Pengembangan Perangkat Pembelajaran Dengan Pendekatan Quantum Learning Pada Mata Kuliah Aljabar Linier Materi Ruang-n Euclides

kompetensi dasar, indikator, materi pokok, model pembelajaran, sumber pembelajaran, kegiatan pembelajaran dan penilaian. Satuan acara perkuliahan yang dikembangkan adalah untuk lima kali pertemuan. Alokasi waktu yang digunakan untuk setiap pertemuan adalah $3 \times 40$ menit.

b. LKM ini disajikan dalam bentuk latihan yang dapat dirumuskan sebagai suatu unit yang lengkap yang berdiri sendiri dan terdiri atas suatu rangkaian kegiatan belajar yang disusun untuk membantu mahasiswa mencapai sejumlah tujuan yang dirumuskan secara khusus dan jelas. Desain LKS yang menarik secara visual diharapkan dapat memotivasi siswa dalam mempelajari materi ini.

c. Tes hasil belajar yang dikembangkan pada penelitian ini disusun berdasarkan indikator hasil belajar. Tes yang dikembangkan berbentuk tes uraian. Penilaian yang digunakan pada tes ini adalah Penilaian Acuan Patokan (PAP). Tes hasil belajar yang dikembangkan terdiri dari empat buah butir soal, sedangkan waktu yang diperlukan untuk menyelesaikan soal tes hasil belajar adalah 120 menit.

\section{4) Perancangan awal instrument penelitian}

Perancangan awal instrumen penelitian terdiri dari lembar validasi perangkat, lembar pengamatan aktivitas mahasiswa, lembar pengamatan pengelolaan pembelajaran, tes hasil belajar, dan lembar respon mahasiswa.

\section{c) Deskripsi Tahap Pengembangan (Develop)}

Tujuan dari tahap pengembangan adalah untuk menghasilkan perangkat pembelajaran yang telah direvisi berdasarkan masukan para ahli, dan data yang diperoleh dari uji coba. Kegiatan pada tahap ini adalah validasi ahli, validasi keterbacaan dan uji coba perangkat.

\section{1) Validasi ahli}


Dalam langkah ini peneliti memberikan perangkat pembelajaran kepada para validator, kemudian para validator memberikan penilaian terhadap perangkat yang telah dibuat oleh peneliti dengan menggunakan lembar validasi. Hasil penilaian para validator mengenai Satuan Acara Perkuliahan (SAP), Lembar Kegiatan Mahasiswa (LKM), dan Tes Hasil Belajar (THB) berupa saran dan pertimbangan.

\section{2) Uji keterbacaan}

Uji keterbacaan dilakukan terhadap Draft II. Uji keterbacaan ini dilakukan sebelum ujicoba. Mahasiswa yang melakukan uji keterbacaan adalah enam mahasiswa kelas $V A$ Program Studi Pendidikan Matematika IKIP PGRI Madiun. Enam mahasiswa yang melakukan uji keterbacaan ini terdiri dari dua mahasiswa yang memiliki kemampuan akademik tinggi, dua mahasiswa yang memiliki kemampuan akademik sedang, dan dua mahasiswa yang memiliki kemampuan akademik rendah. Uji keterbacaan tes hasil belajar dilakukan dengan meminta mahasiswa untuk membaca dan memberi tanda jika ada penjelasan atau kalimat yang sulit dimengerti pada soal tes hasil belajar.

Berdasarkan analisis uji keterbacaan Lembar Kegiatan Mahasiswa (LKM) diperoleh kesimpulan bahwa isi dan tampilan LKM menarik tetapi ada sedikit penjelasan atau kalimat yang sulit dimengerti. Penjelasan atau kalimat yang sulit dimengerti ini diketahui oleh peneliti berdasarkan tanda yang diberikan pada penjelasan atau kalimat yang sulit dimengerti oleh mahasiswa. Keenam mahasiswa diminta untuk memberi tanda pada penjelasan atau kalimat yang sulit dimengerti yang ada pada LKM. 
Pengembangan Perangkat Pembelajaran Dengan Pendekatan Quantum Learning Pada Mata Kuliah Aljabar Linier Materi Ruang-n Euclides

\section{3) Ujicoba perangkat pembelajaran}

Ujicoba perangkat pembelajaran dilaksanakan sebanyak 5 kali pertemuan sesuai dengan Satuan Acara Perkuliahan (SAP) yang telah dikembangkan. Perangkat pembelajaran yang diujicobakan adalah perangkat pembelajaran yang sudah direvisi berdasarkan hasil uji keterbacaan. Penelitian ujicoba dilaksanakan di kelas $V$ B Program Studi Pendidikan Matematika IKIP PGRI Madiun

\section{d) Hasil Pengamatan Aktivitas Mahasiswa selama Pembelajaran}

Pengamatan aktivitas mahasiswa dilakukan terhadap 33 orang mahasiswa selama lima kali pelaksanaan pembelajaran berturut-turut (5 SAP). Di bawah ini disajikan data hasil pengamatan aktivitas mahasiswa selama pembelajaran pendekatan Quantum Learning.

Tabel 1. Aktivitas Mahasiswa selama Pelaksanaan

Pembelajaran pada Kelas Ujicoba

\begin{tabular}{|c|c|c|c|}
\hline No & $\begin{array}{c}\text { Pertemuan } \\
\text { ke- }\end{array}$ & $\begin{array}{c}\text { Jumlah Mahasiswa } \\
\text { yang Aktif Berdasarkan 10 } \\
\text { Aspek Pengamatan }\end{array}$ & $\begin{array}{c}\text { Persentase } \\
\text { Mahasiswa } \\
\text { yang Aktif } \\
\text { (\%) }\end{array}$ \\
\hline 1 & 1 & 172 & $52,12 \%$ \\
\hline 2 & 2 & 181 & $54,84 \%$ \\
\hline 3 & 3 & 191 & $57,87 \%$ \\
\hline 4 & 4 & 194 & $58,78 \%$ \\
\hline 5 & 5 & 213 & $64,54 \%$ \\
\hline
\end{tabular}

Berdasarakan data yang terdapat pada tabel di atas diperoleh bahwa aktivitas mahasiswa pada pertemuan ke-1, 2, 3, dan 4 belum memenuhi kriteria batasan keefektifan pembelajaran karena belum mencapai 60\% yang melakukan aktivitas berdasarkan 10 aspek pengamatan, seperti yang telah diuraikan pada BAB III. Sedangkan pada pertemuan ke-5 mahasiswa sudah memenuhi kriteria, yaitu telah melakukan aktivitas lebih dari 60\%. Hal ini berarti dapat disimpulkan bahwa aktivitas mahasiswa dikatakan efektif. 
e) Hasil Penilaian Kemampuan Dosen dalam Mengelola Pembelajaran

Berdasarkan hasil penilaian kemampuan dosen dalam mengelola pembelajaran diperoleh bahwa rata-rata skor kemampuan dosen dalam mengelola pembelajaran pada tahap pendahuluan, kegiatan inti, dan penutup, serta kemampuan mengelola waktu, dan suasana kelas minimal 3. Hasil analisis data ini menunjukkan bahwa rata-rata skor kemampuan dosen dalam mengelola pembelajaran untuk pertemuan 1, 2, 3, 4 dan 5 mempunyai kriteria minimal baik. Berdasarkan kriteria yang sudah dijelaskan pada BAB III, maka dosen dalam mengelola pembelajaran memenuhi kriteria baik.

f) Nilai Kemampuan Mahasiswa dalam Memahami Materi

Kemampuan mahasiswa dalam memahami materi diamati pada setiap kali pembelajaran. Berdasarkan hasil penilaian diperoleh bahwa rata-rata skorkemampuan mahasiswa dalam memahami materi minimal 3. Berdasarkan analisis data yang telah diuraikan pada BAB V, maka dapat disimpulkan bahwa kemampuan mahasiswa dalam memahami materi minimal baik.

\section{g) Hasil Ujicoba Tes Hasil Belajar}

Hasil analisis sensitivitas butir tes, validitas butir tes, dan reliabilitas tes selama tes ujicoba perangkat pembelajaran pendekatan Quantum Learning adalah sebagai berikut:

\section{1) Sensitivitas Butir Tes}

Berdasarkan analisis sensitivitas butir tes menunjukkan bahwa setiap butir tes hasil belajar peka atau sensitif terhadap pembelajaran. Hal ini berarti bahwa semua butir tes dikatakan sensitif, sehingga layak untuk digunakan.

Tabel 2. Analisis Sensitivitas Butir Tes

\begin{tabular}{|c|c|c|}
\hline No. Soal & Sensitivitas & Interprestasi \\
\hline 1 & 0,486 & Sensitiv/Peka \\
\hline 2 & 0,519 & Sensitiv/Peka \\
\hline
\end{tabular}


Pengembangan Perangkat Pembelajaran Dengan Pendekatan Quantum Learning Pada Mata Kuliah Aljabar Linier Materi Ruang-n Euclides

\begin{tabular}{|l|l|l|}
\hline 3 & 0,538 & Sensitiv/Peka \\
\hline 4 & 0,571 & Sensitiv/Peka \\
\hline 5 & 0,669 & Sensitiv/Peka \\
\hline
\end{tabular}

\section{2) Validitas Butir Tes}

Berdasarkan rumus korelasi Product Moment, menunjukkan bahwa tingkat validitas dari masing-masing butir tes berada pada kategori tinggi dan kategori sangat tinggi. Hal ini berarti bahwa semua butir tes dikatakan valid, sehingga layak untuk digunakan.

Tabel 3. Analisis Validitas Butir Tes

\begin{tabular}{|c|c|c|}
\hline No & $\mathbf{r}_{\mathrm{xy}}$ & Tingkat Validitas \\
\hline 1 & 0,752 & Tinggi \\
\hline 2 & 0,788 & Tinggi \\
\hline 3 & 0,781 & Tinggi \\
\hline 4 & 0,806 & Sangat Tinggi \\
\hline 5 & 0,838 & Sangat Tinggi \\
\hline
\end{tabular}

\section{3) Reliabilitas}

Reliabilitas instrumen tes hasil belajar yang dikembangkan termasuk pada kategori sangat tinggi. Hal ini berarti bahwa instrumen tes hasil belajar reliabel sehingga layak untuk digunakan.

\section{h) Hasil Angket Respon Mahasiswa}

Berdasarkan analisis hasil angket respon mahasiswa pada saat tes uji coba perangkat pembelajaran pendekatan Quantum Learning diperoleh bahwa 89,33\% mahasiswa yang memberikan respon positif dan 10,67\% mahasiswa yang memberikan respon negatif terhadap pertanyaan dalam angket, sehingga respon mahasiswa terhadap pembelajaran pendekatan Quantum Learning positif.

\section{Pembahasan Hasil Penelitian}

Pada pembahasan hasil penelitian ini dibahas pencapaian kriteria perangkat pembelajaran dengan pendekatan Quantum Learning. 
Pencapaian kriteria perangkat pembelajaran dengan pendekatan Quantum Learningdapat dilihat pada tabel berikut ini :

Tabel 4. Pencapaian Kriteria Perangkat Pembelajaran dengan Pendekatan Quantum Learning

\begin{tabular}{|c|l|c|}
\hline No & \multicolumn{1}{|c|}{ Aspek Kategori } & Keterangan \\
\hline 1 & Aktivitas mahasiswa & Efektif \\
\hline 2 & $\begin{array}{l}\text { Kemampuan dosen dalam } \\
\text { mengelola pembelajaran }\end{array}$ & Baik \\
\hline 3 & $\begin{array}{l}\text { Kemampuan mahasiswa } \\
\text { dalam memahami materi }\end{array}$ & Sensitif, valid, dan reliabel \\
\hline 4 & Tes hasil belajar & Positif \\
\hline 5 & Respon mahasiswa & \\
\hline
\end{tabular}

Tabel di atas menunjukkan bahwa berdasarkan hasil penelitian didapatkan perangkat pembelajaran dengan pendekatan Quantum Learning pada materi Ruang-n Euclides dengan menggunakan model 4-D yang telah dimodifikasi. Perangkat pembelajaran yang didapatkan pada penelitian yang dilakukan di kelas VA Program Studi Pendidikan Matematika IKIP PGRI Madiun meliputi Satuan Acara Perkuliahan (SAP), Lembar Kegiatan Mahasiswa (LKM), dan Tes Hasil Belajar (THB).

\section{Kesimpulan}

Kesimpulan yang didapatkan berdasarkan hasil penelitian adalah perangkat pembelajaran dengan pendekatan Quantum Learning dikembangkan dengan menggunakan model pengembangan 4-D yang dimodifikasi. Pengembangan perangkat pembelajaran pada penelitian ini dilakukan sampai tahap ketiga, yaitu pendefinisian (define), perancangan (design), dan pengembangan (develop). Perangkat pembelajaran Quantum Learning yang baik telah didapatkan dengan menggunakan model 4-D ini. Hal ini karena perangkat pembelajaran yang telah didapatkan dinyatakan valid oleh para validator dan memenuhi kriteria aktivitas mahasiswa efektif, kemampuan dosen mengelola pembelajaran baik, kemampuan mahasiswa dalam memahami materi, tes hasil belajar sensitif, valid, dan reliabel Perangkat pembelajaran dengan pendekatan Quantum Learning yang 
Pengembangan Perangkat Pembelajaran Dengan Pendekatan Quantum Learning Pada Mata Kuliah Aljabar Linier Materi Ruang-n Euclides

dihasilkan meliputi Satuan Acara Perkuliahan (SAP), Lembar Kegiatan Mahasiswa (LKM), dan Tes Hasil Belajar (THB).

\section{Daftar Pustaka}

Arikunto, Suharsimi. 2003. Dasar-Dasar Evaluasi Pendidikan. Jakarta: Bumi Aksara.

Dara, Fornichly Revi. 2009. Pembelajaran Matematika Realistik untuk Materi Balok dan Kubus di Kelas VII SMP Negeri 1 Nabire. Tesis. PPs Unesa Surabaya

DePorter, B. \& Hernacki, M.. 2010. Quantum Learning: membiasakan Belajar Nyaman dan Menyenangkan. Bandung: Kaifa.

Slavin, E.. R.1994. Educational Psychology, 4thed. London: Allyn and Bacon.2008. Cooperatie Learning. Bandung: Nusa Media.

Suwarna, dkk. 2006. Pengajaran Mikro Pendekatan Praktis Dalam Menyiapkan Pendidik Profesional. Yogyakarta: Tiara Wacana.

Thiagarajan, S., Semmel, D. S. dan Semmel, M. I. 1974. Instructional Development for Training Teachers of Exceptional Children. Minnesota: University of Minnesota

Trianto. 2009. Mendesain Pendekatan Pembelajaran Inovatif Progresif. Jakarta: Kencana Prenada Media Group

\section{Tri Andari}

Dosen Prodi PMTK, IKIP PGRI Madiun

E-mail: - 
Tri Andari 